\title{
Terminalia catappa L. extract improves survival, hematological profile and resistance to Aeromonas hydrophila in Betta sp.
}

\author{
Rudy Agung Nugroho, Hetty Manurung, Firman M. Nur, Widha Prahastika
}

Received - 16 September 2016/Accepted - 09 June 2017. Published online: 30 June 2017; Inland Fisheries Institute in Olsztyn, Poland Citation: Nugroho R.A., Manurung H., Nur F.M., Prahastika W. 2017 - Terminalia catappa L. extract improves survival, hematological profile and resistance to Aeromonas hydrophila in Betta sp. - Arch. Pol. Fish. 25: 103-115.

\begin{abstract}
To determine the effects of Terminalia catappa extract (TCE) immersion on the survival and hematological profile of Betta sp, a group of fish was immersed in 500 ppm TCE and compared with the control group. After three days of immersion, survival, leukocyte (WBC), erythrocyte (RBC), hemoglobin (Hb), hematocrit (Hct), platelet (PLT), and differential leukocyte counts were compared between the two groups. Surviving fish from each group were then divided into three subgroups: subgroup without injection; subgroup injected with normal saline; subgroup injected with Aeromonas hydrophila. Survival, WBC, RBC, Hb, Hct, PLT, the percentage and number of lymphocyte, monocyte, and granulocytes post injection were evaluated for $48 \mathrm{~h}$. The results showed that the survival of immersed fish was significantly higher than that in the control. No significant differences in the hematological profile were noted between the control and the immersed fish. The WBC of control subgroup (A. hydrophila injection) was significantly increased after $24 \mathrm{~h}$. The fish immersed and injected with $A$. hydrophila had the highest PLT. The number of lymphocytes of all subgroups of fish was stable while the percentage of monocytes and granulocytes of the subgroups of immersed fish were increased. This finding suggested that $500 \mathrm{ppm}$ of TCE is beneficial for improving survival, blood profile, and resistance to A. hydrophila.
\end{abstract}

Keywords: Terminalia catappa, survival, blood profiles, Betta sp., Aeromonas hydrophilla

\footnotetext{
R.A. Nugroho [ڤ], H. Manurung, F.M. Nur, W. Prahastika Animal Physiology, Development and Molecular Laboratory, Department of Biology, Faculty of Mathematic and Natural Science, Mulawarman University, Jl. Barong Tongkok No 4, Gn Kelua, Samarinda, East Kalimantan 75123, Indonesia e-mail: rudyagung.nugroho@fmipa.unmul.ac.id
}

\section{Introduction}

Aeromonas species have been identified as causative agents and serious pathogens to various aquatic animals (Carriero et al. 2016, Maliwat et al. 2016, Ni et al. 2016, Yang et al. 2016) resulting in mass mortalities to many cultured ornamental fish (Majtán et al. 2012, Abdi et al. 2014, Harikrishnan et al. 2015). Among various Aeromonas species, Aeromonas hydrophila is known to cause disease outbreaks in Labeo rohita (Hamilton) (Das et al. 2015), goldfish, Carassius auratus (L.) (Anusha et al. 2014, Sahoo et al. 2016), and red hybrid tilapia (Oreochromis spp.) (Kirubakaran et al. 2016, Lee et al. 2016, Musthafa et al. 2016). Intramuscular injection of $A$. hydrophila can produce a virulent reaction and reduce immune responses in Pangasianodon hypophthalmus (Sauvage) (Tamamdusturi and Yuhana 2016). To overcome high mortalities of cultured animals, aquaculturists and researchers use antibiotics to prevent virulent reactions to $A$. hydrophila infection (Guz and Kozinska 2004, Sinclair et al. 2016).

However, increasing global demand for the preservation of eco-friendly environments, the application of antibiotics, which are notorious for increasing antibiotic-resistant pathogens and inducing environmental deterioration, is being questioned (Samanidou and Evaggelopoulou 2007, He et al. 2016, Uchida et al. 2016). Alternatively, various

(C) Copyright by Stanisław Sakowicz Inland Fisheries Institute in Olsztyn.

(C) 2017 Author(s). This is an open access article licensed under the Creative Commons Attribution-NonCommercial-NoDerivs License (http://creativecommons.org/licenses/by-nc-nd/3.0/). 
plant extracts, such as oat (Avena sativa), oyster mushroom (Pleurotus ostreatus), nettle (Urtica dioica), sea grass (Cymodocea serrulata), turmeric (Curcuma longa), spirulina (Spirulina platensis), and beet root (Beta vulgaris) have been tested and used as alternatives to antibiotics (Baba et al. 2016, Bilen et al. 2016, Devi et al. 2016). There has been a surge in the use of plant extracts to enhance the survival and immune competence of cultured aquatic animals (Reverter et al. 2014, Adel et al. 2016, Kakaei and Shahbazi 2016).

One potential plant that can be used as an antimicrobial to enhance survival and immunocompetence is the Indian almond tree $(T$. catappa). Terminalia species are widely distributed in both tropical and sub-tropical regions, including in Asian (Hyttel et al. 2010). In Indonesia, T. catappa L. is an attractive, long-lived tree well suited to ornamental and amenity plantings. The water extract of $T$. catappa leaf is well known as a folk medicine for antipyretic, hemostatic, hepatitis, and liver-related diseases in the Philippines, Malaysia, and Indonesia (Meena and Raja 2006, Vučurović and Razmovski 2012).

According to Rakholiya and Chanda (2012), T. catappa extract (TCE) shows the highest and strongest synergistic effect against the bacterial strains tested. Meanwhile, a study in fish revealed that TCE can be used as an alternative antibacterial remedy against tilapia, Oreochromis niloticus (L.) parasites and bacterial pathogens (Öztop et al. 2002, Goh et al. 2010). According to Pandey (2013), TCE is also a potential plant biomedicine for improving the non-specific defense mechanism in fish and elevating the specific immune response. The use of TCE in O. niloticus (Chitmanat et al., 2003) and post-larval black tiger shrimp, Penaeus monodon, (Ikhwanuddin et al. 2014) also improved their survival and immunity. Further, TCE also increased the hematological profiles of African catfish, Clarias gariepinus (Burchell) (Julius et al. 2015). Additionally, TCE with phytochemical active ingredients such as flavonoid is useful for boosting immune function and an antioxidant enzyme that is responsible for preventing cellular damage and improving immune competence (Middleton and Kandaswami 1992, Middleton 1998, Saroja et al. 2012).

The immune status of fish is related to their hematological parameters, which are important in fish culture because of their value in monitoring the health status of fish (Chandel et al. 2009). Hematological parameters such as red blood cell (RBC), hemoglobin count $(\mathrm{Hb})$, hematocrit $(\mathrm{Hct})$, platelet (PLT), and total and differential leukocyte counts (TLC and DLC) in fish are effective tools that can be used to evaluate physiological and pathological changes in fish (Inama et al. 1993). Leukocyte counts are used regularly as indicators of fish health status because leukocytes are key components of innate immune defense and are involved in the regulation of immunological function in fish (Zhou et al. 2010, Ekman et al. 2013). Moreover, immunity related physiological responses measured by alterations in TLC and DLC can be used as indicators of immune competence and the health status of several fish species (Alvarez et al. 1988, Modrá et al. 1998, Do Huu et al. 2016).

The ornamental fish Betta sp. is a member of the Labyrinth fish family (Belonitiidae) and is known as a colorful species, especially in males (Ekman et al. 2013). As an important cultured ornamental species in Indonesia, Betta sp. is recognized as a substantial ornamental fish commodity (Alfian 2010). Increasing market demand for this fish has led to a significant boost in research to improve the survival and health performance of it.

However, information regarding the effects of TCE immersion on the survival and immune competence of ornamental fish when challenged with $A$. hydrophila is unknown. Thus, the current study was designed to evaluate the effects of TCE immersion on survival, RBC, Hb, Hct, PLT, TLC, and DLC, including the number and percentage of lymphocytes, monocytes, and granulocytes in Betta sp. when challenged with $A$. hydrophila. 


\section{Materials and methods}

\section{Plant material}

Dried, cut brown T. catappa leaves were collected on the campus of Mulawarman University, Barong Tongkok, East Kalimantan, Indonesia. To eliminate extraneous matter, the collected T. catappa leaves were washed with deionized water and immediately dried in an oven at $40^{\circ} \mathrm{C}$ for $12 \mathrm{~h}$. T. catappa powder was obtained using a mill. The powder was extracted with ethanol $95 \%$ for 3 days (100 g per $100 \mathrm{~mL}$ ). After filtration, the extract was evaporated using a rotary evaporator and stored at $4^{\circ} \mathrm{C}$ until it was used as a crude extract.

To detect the presence of possible phytochemicals in the crude extract of $T$. catappa leaves, some preliminary phytochemical tests for alkaloid, saponin, steroid, triterpenoid, quinon, phenolic, tannin, and flavonoid were performed as follows: (1) Alkaloid-Dragendorff Test $-2 \mathrm{~mL}$ of the filtrate was added to $1 \mathrm{~mL}$ of Dragendorff reagent along the side of the test tube, an orange or orange-reddish-brown precipitate indicated a positive test, (2) test for saponin $-1 \mathrm{~mL}$ of extract $+5 \mathrm{~mL}$ distilled water was shaken vigorously, the appearance of stable froth for 15 minutes indicated the presence of saponin, (3) test for steroids and (4) triterpenoid (Liebermann-Burchard): $-2 \mathrm{~mL}$ extract $+1 \mathrm{~mL}$ chloroform + a few drops of acetic anhydride + concentrated sulphuric acid added along the side of the test tube, the appearance of a blue or green color indicated the presence of steroids, while the appearance of a red or brown color indicated the presence of triterpenoid, (5) test for Quinon - $1 \mathrm{~mL}$ of extract $+1 \mathrm{~mL}$ of concentrated sulfuric acid, a red color indicated the presence of quinon, (6) test for phenols and tannins crude extract was mixed with $2 \mathrm{~mL}$ of $2 \%$ solution of $\mathrm{FeCl}_{3}$, a blue-green or black color indicated the presence of phenols and tannins, (7) test for flavonoids $2 \mathrm{~mL}$ extract + concentrated hydrochloric acid + magnesium ribbon, the appearance of pink-red color indicated the presence of flavonoids.

\section{Animals and experimental setup}

Three hundred and sixty two-month old fish (average initial weight $0.62 \mathrm{~g}$ ) were purchased from a local breeding farm in Samarinda, East Kalimantan (Indonesia) and acclimated at the Animal Physiology, Development, and Molecular Laboratory, Mulawarman University, East Kalimantan for three days. The fish were then randomly distributed into two groups (C and $\mathrm{P}$ ) with triplicate groups of twenty fish per replicate group. Each fish was then placed in an individual glass tank $(0.5 \mathrm{~L}$ capacity, $0.4 \mathrm{~L}$ of freshwater in each tank). For three days, 500 ppm TCE was added to the fish in group P (Immersion), while there was no immersion in group $\mathrm{C}$ (Control). Temperature, $\mathrm{pH}$, and dissolved oxygen (DO) were measured daily with a thermometer and a HM-7 pH meter (TOA-DKK Corporation, Japan). Nitrate, nitrite, and ammonium were measured and recorded weekly using chemical test kits (Aquarium Pharmaceuticals ${ }^{\mathrm{TM}}$, Inc., USA). The fish in each glass tank was fed with frozen blood worm at a ratio of $1 \%$ of body weight every day. The optimum immersion (500 ppm) and feeding rations were determined during previous experiments (Nugroho et al. 2016). Uneaten food and feces were siphoned out before renewing the water. The water volume was renewed every day at a concentration of 500 ppm (only for group P) and maintained at $0.4 \mathrm{~L}$ of water in every glass tank.

\section{Challenge test}

At the end of the trial, both groups of fish ( $\mathrm{C}$ and $\mathrm{P}$ ) were further divided into three triplicate subgroups each (20 fish per replicate). Two subgroups, one from each group, were injected with $20 \mu \mathrm{L}$ of $A$. hydrophila stock suspension $\left(10^{6} \mathrm{CFU} \mathrm{mL}^{-1}\right)$ that was obtained from the Department of Biology, Faculty of Mathematics and Natural Sciences, Mulawarman University, Indonesia; two subgroups from each group were injected with $20 \mu \mathrm{L}$ normal saline solution and; the third and final two subgroups from each group were not injected (control subgroup). All injections were performed 
intraperitoneally. All fish were then monitored for survival, RBC, Hb, Hct, PLT, TLC, and DLC, including the number and percentage of lymphocytes, monocytes, and granulocytes at 0,24 , and $48 \mathrm{~h}$ post-injection time.

\section{Sampling and analytical procedure}

The survival rate of the fish in each group was recorded daily during the pre-challenge test and every $24 \mathrm{~h}$ post injection for 48 hours. At day three after immersion and every $24 \mathrm{~h}$ interval during the challenge test, blood samples were taken by caudal venipuncture after anesthetizing the fish with MS-222 $\left(200 \mathrm{mg} \mathrm{L}^{-1}\right)$. Total RBC $\left(10^{6}\right.$ per $\left.\mathrm{mm}^{3}\right)$ and WBC $\left(10^{3}\right.$ per $\mathrm{mm}^{3}$ ) were determined manually with the improved Neubauer counting chamber. Hemoglobin $(\mathrm{Hb})$ was determined according to the cyanmethemoglobin procedure (Blaxhall and Rao 1973) and expressed in $\mathrm{g} \mathrm{dL}^{-1}$. The number and percentage of lymphocytes, monocytes, granulocytes, Htc, and PLT were determined using an Mindray BC2800 Auto Hematology Analyser (Mindray ${ }^{\circledR}$ Shenzhen, China).

\section{Statistical analysis}

Results are expressed as means \pm standard error (SE) and the data were analyzed using SPSS version 21 (SPSS, Inc., USA). The data on survival, the percentage of lymphocytes, monocytes, and granulocytes were transformed to arcsine. The WBC, RBC, $\mathrm{Hb}$, the number of lymphocytes, monocytes, and granulocytes on day three after immersion were subjected to the T-test to evaluate the significance of differences among groups. Meanwhile, survival, WBC, $\mathrm{RBC}, \mathrm{Hb}, \mathrm{Htc}, \mathrm{PLT}$, the percentage and number of lymphocytes, monocytes, and granulocytes during the challenge test were subjected to two way ANOVA, followed by Tukey's post hoc test to evaluate significant differences among the groups of treatments. All tests were significant at $\mathrm{P}<0.05$.

\section{Results}

The screening test for bioactive compounds in TCE must be done to determine the benefit of phytochemical bioactive agents in fish. The current study showed the presence of saponin, triterpenoid, quinon, phenolic, tannins, and flavonoid in the TCE (Table 1).

\section{Table 1}

Phytochemical screening test of $T$. catappa leaf extract. (+) Present; (-) Absent

\begin{tabular}{ll}
\hline \hline Phytochemicals & Results \\
\hline \hline Alkaloid & - \\
Saponin & + \\
Steroid & - \\
Triterpenoid & + \\
Quinon & + \\
Phenolic & + \\
Tanin & + \\
Flavonoid & + \\
\hline
\end{tabular}

During the three days of the immersion treatment, the temperature, $\mathrm{pH}, \mathrm{DO}$, nitrate, nitrite, and ammonia levels were recorded as follow: temperature $-27.9^{\circ} \mathrm{C} \pm 0.3, \mathrm{pH}-7.37 \pm 0.2$, and dissolved oxygen level $-8.2 \pm 0.3 \mathrm{mg} \mathrm{L}^{-1}$. The nitrate, nitrite, and ammonia levels in the water of the control and 500 ppm TCE treatment groups were below the limits of detection.

The survival and hematological profiles of the control group and the group of fish immersed in 500 ppm TCE are presented in Table 2. After three days of immersion, the survival of fish in the TCE immersion was significantly higher (T-test, $\mathrm{P}<0.05)$ than in the control group, whereas blood parameters such as WBC, RBC, Hb, Htc, PLT, and the number of lymphocytes, monocytes, and granulocytes were not affected by 500 ppm TCE immersion.

After being challenged with $A$. hydrophila, the survival rates of fish without immersion were significantly lower $(\mathrm{P}<0.05)$ than those of the other fish 
Table 2

Mean \pm SE (standard error) survival and blood profile of Betta sp. after three-day immersion in 500 ppm T. catappa leaf extract

\begin{tabular}{lll}
\hline \hline & \multicolumn{2}{l}{ Groups } \\
\cline { 2 - 3 } Parameters & Control & $500 \mathrm{ppm}$ \\
\hline \hline Survival $(\%)$ & $88.88^{\mathrm{a}} \pm 0.5$ & $98.88^{\mathrm{b}} \pm 2.42$ \\
WBC $\left(10^{3} \mu \mathrm{L}^{-1}\right)$ & $8.32 \pm 0.21$ & $8.38 \pm 0.12$ \\
$\mathrm{RBC}\left(10^{6} \mu \mathrm{L}^{-1}\right)$ & $1.64 \pm 0.14$ & $1.72 \pm 0.04$ \\
$\mathrm{Hb}\left(\mathrm{g} \mathrm{dL} \mathrm{L}^{-1}\right)$ & $6.22 \pm 0.46$ & $6.11 \pm 0.38$ \\
Htc $(\%)$ & $18.66 \pm 1.40$ & $16.66 \pm 0.47$ \\
Lymphocytes $\left(10^{3} \mu \mathrm{L}^{-1}\right)$ & $7.00 \pm 1.01$ & $5.00 \pm 0.23$ \\
Monocytes $\left(10^{3} \mu \mathrm{L}^{-1}\right)$ & $1.22 \pm 0.22$ & $1.66 \pm 0.23$ \\
Granulocytes $\left(10^{3} \mu \mathrm{L}^{-1}\right)$ & $1.77 \pm 0.22$ & $1.88 \pm 0.20$ \\
PLT $\left(10^{3} \mu \mathrm{L}^{-1}\right)$ & $34.88 \pm 1.04$ & $35.77 \pm 1.81$ \\
\hline
\end{tabular}

WBC - White blood cell; RBC - Red blood cell; Hb - Hemoglobin; Htc - Hematocrit; PLT - Platelet. Different letter indexes (a, b) indicate significantly different means for different treatments at $\mathrm{P}<0.05$.

(Fig. 1). The WBC counts of the control fish increased significantly after the challenge with $A$. hydrophila. The highest WBC count $\left(12.36 \pm 0.19 \times 10^{3} \mu \mathrm{L}^{-1}\right)$ was noted in the control fish subgroup at $48 \mathrm{~h}$ post challenge (Table 3). Meanwhile, the PLT of TCE-immersed fish that were injected with the $A$. hydrophila pathogen was significantly the highest $(\mathrm{P}$ $<0.05)$ at $24 \mathrm{~h}$ post challenge, followed by a decline in the number of PLT at $48 \mathrm{~h}$ post challenge. The $\mathrm{RBC}, \mathrm{Hb}$, and Hct of all subgroups of fish were not significantly different during the challenge test.

During the challenge test, the 500 ppm TCE-immersed fish had the lowest percentage of lymphocytes. However, the highest percentage of monocytes and granulocytes were found in the subgroups of infected fish that had been immersed in

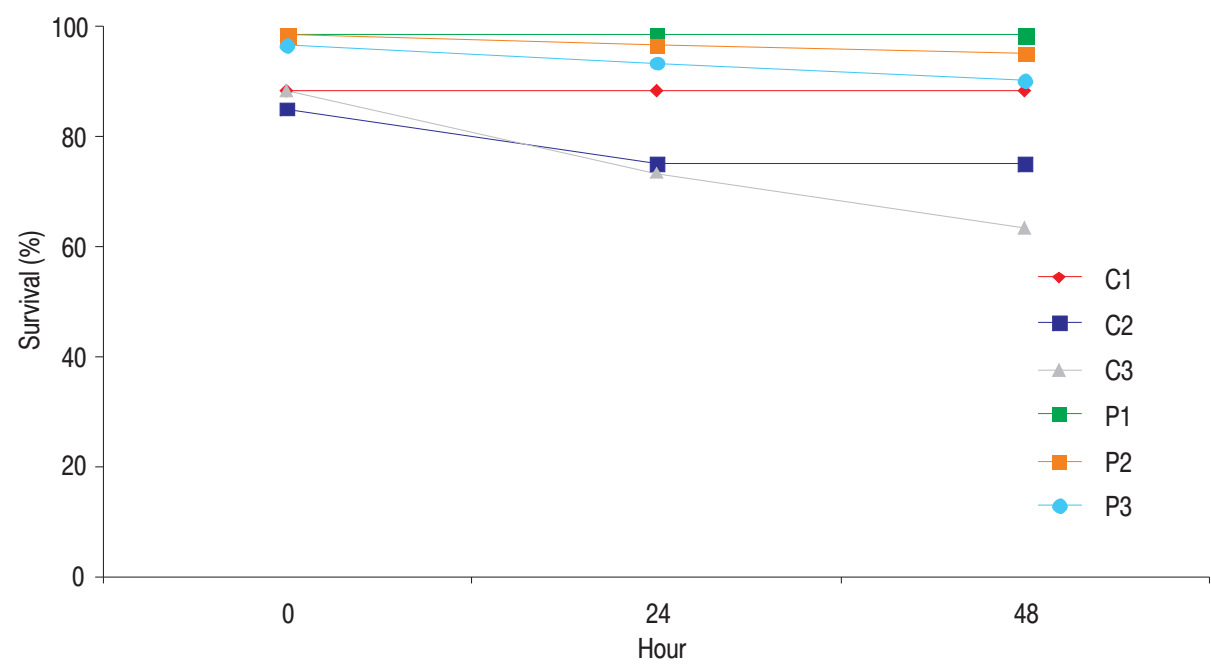

Figure 1. Survival of Betta sp. challenged with A. hydrophila. Note: C1 - control with no injection; C2 - control with $20 \mu \mathrm{L}$ normal saline injection; C3 - control with $20 \mu \mathrm{L}$ A. hydrophila injection; P1 - 500 ppm T. catappa leaf extract (TCE) immersion with no challenge; P2 - 500 ppm immersion with $20 \mu \mathrm{L}$ normal saline injection; P3 - 500 ppm immersion with $20 \mu \mathrm{L}$ A. hydrophila injection. *Significant difference at P $<0.05$. 

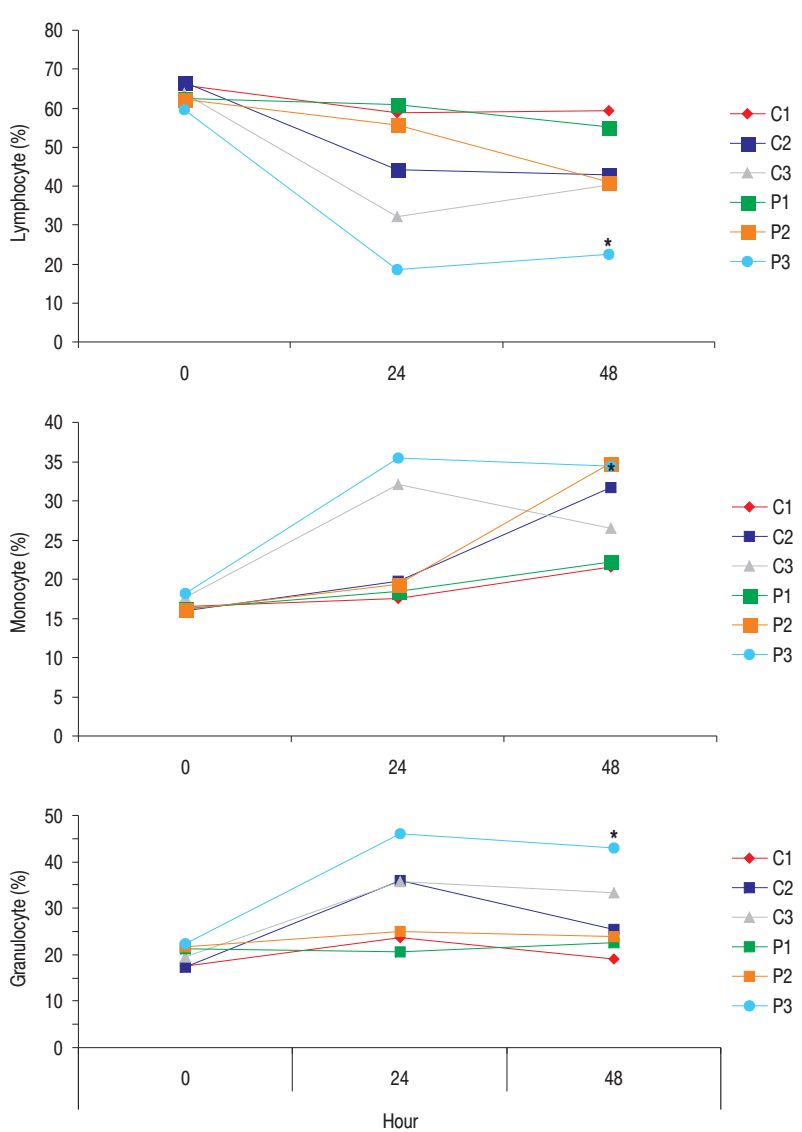

Figure 2. Lymphocyte, monocyte, and granulocyte count percentages in the blood of Betta sp. Note: C1 - control with no injection; $\mathrm{C} 2$ - control with $20 \mu \mathrm{L}$ normal saline injection; C3 - control with $20 \mu \mathrm{L}$ A. hydrophila injection; P1 - 500 ppm T. catappa leaf extract (TCE) immersion with no challenge; P2 - 500 ppm immersion with $20 \mu \mathrm{L}$ normal saline injection; P3 - 500 ppm immersion with $20 \mu \mathrm{L}$ A. hydrophila injections. *Significant difference at $\mathrm{P}<0.05$.

500 ppm TCE (Fig. 2). The number of lymphocytes of all subgroups of fish was stable during the challenge test, whereas the number of monocytes and granulocytes of all the subgroups of fish were significantly increased $24 \mathrm{~h}$ post challenge. The highest number of monocytes and granulocytes were noted in the TCE-immersed fish challenged with A. hydrophila $48 \mathrm{~h}$ post injection (Fig. 3).

\section{Discussion}

Over the past few years, infectious diseases caused by $A$. hydrophila have become a major problem in fish culture causing heavy economic losses because of high mortalities. Plant-based extracts have been proven to enhancesurvival and immunocompetence in cultured fish. A number of plant extracts that have active ingredients and various biological activities have been reported as suitable for use as supplements in aquaculture (Citarasu 2010, Madhuri et al. 2013, Chakraborty et al. 2014, Sivasankar et al. 2015, Syahidah et al. 2015). The current study indicates that the application of 500 ppm TCE, which contains active phytochemical compounds such as saponin, triterpenoid, quinon, phenolic, tannins, and flavonoid, can significantly improve the survival of Betta sp. even when they are challenged with $A$. hydrophila. Similarly, improved survival of $A$. hydrophila-infected goldfish (C. auratus) fed herbal plant extract (Ixora coccinea) has also been reported (Anusha et al. 2014).

Plant-based bioactive compounds are mostly biodegradable in nature, ecofriendly, safe for humans, biocompatible, and usually less expensive than synthetic compounds (Immanuel et al. 2009). Several phytochemical compounds such as saponin, triterpenoid, quinon, phenolic, tannins, and flavonoid are found in various parts of some plants, including the leaves of T. catappa (Citarasu 2010, Chakraborty et al. 2014). The phytochemicals which are contained in the plant may boost the innate immune system and could be used widely in fish culture (Chakraborty and Hancz 2011). Some previous studies have been conducted to determine the use of phytochemicals from various parts of plant extracts to increase survival rates of marine ornamental fish (Balachandran and Tissera 2013), Nile tilapia (O. niloticus) (Abdel-Tawwab et al. 2010, Akinwande et al. 2011) and common carp, Cyprinus carpio L. (Soltanian and Fereidouni 2016) against $A$. hydrophila.

\section{Survival}

The current study found that immersing fish for three days in TCE and the subgroups of TCE-immersed fish with or without injections exhibited significantly higher $(\mathrm{P}<0.05)$ survival rates than did the control 

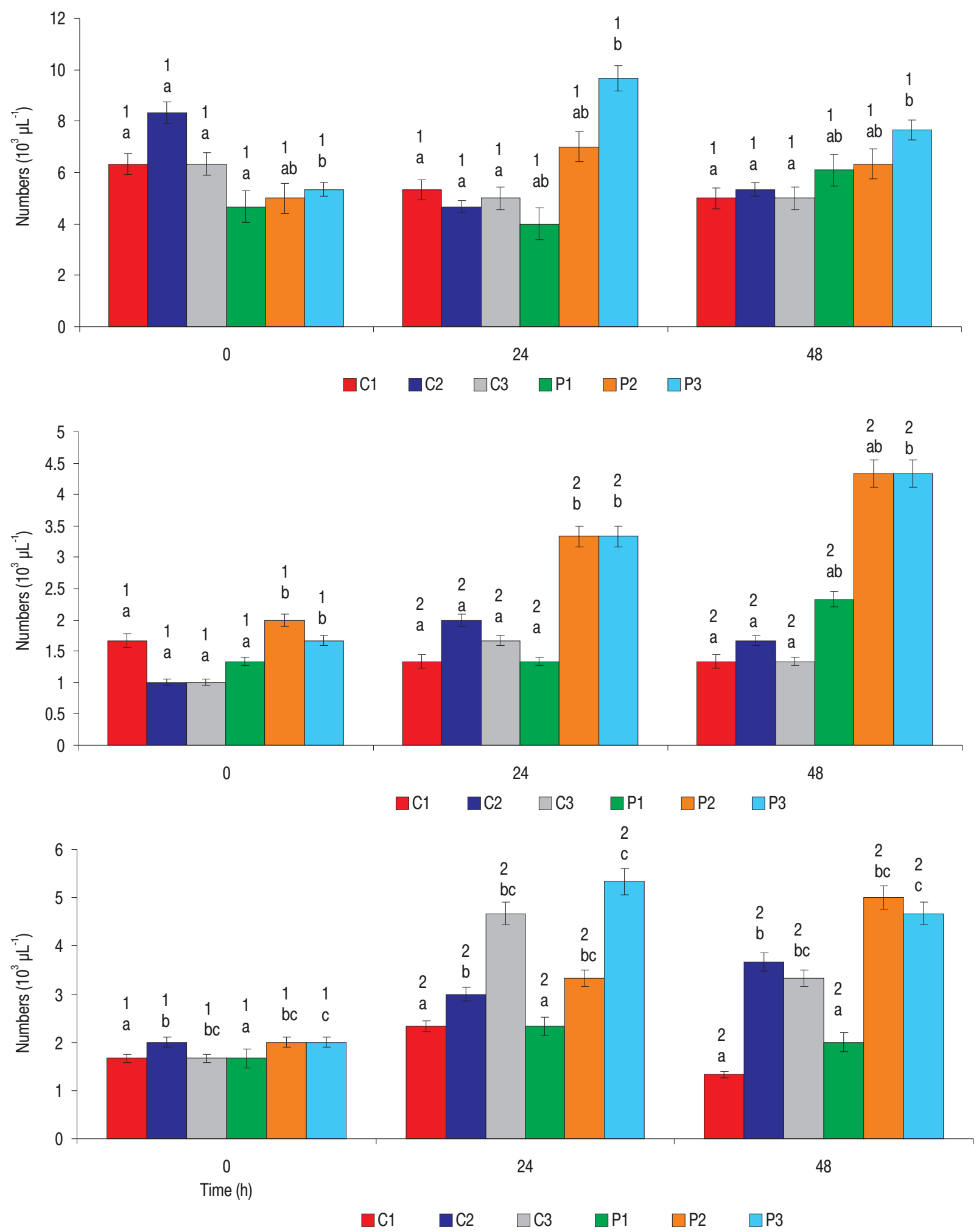

Figure 3. Lymphocyte, monocyte, and granulocyte count numbers in the blood of Betta sp. challenged with A. hydrophila. Different letter indexes ( $\mathrm{a}, \mathrm{b}, \mathrm{c})$ over bars indicate significantly different means for different treatments at $\mathrm{P}<0.05$. Different numerical indexes $(1,2,3)$ over bars indicate significantly different means at different times at $\mathrm{P}<0.05$. Note: $\mathrm{C} 1$ - control with no injection; $\mathrm{C} 2-\mathrm{control}$ with $20 \mu \mathrm{L}$ normal saline injection; C3 - control with $20 \mu \mathrm{L}$ A. hydrophila injection; P1 - 500 ppm T. catappa leaf extract (TCE) immersion with no challenge; P2 - 500 ppm immersion with $20 \mu \mathrm{L}$ normal saline injection; P3 - 500 ppm immersion with $20 \mu \mathrm{L}$ A. hydrophila injections. 
Table 3

Mean \pm SE blood profile of Betta sp. challenged with A. hydrophila

\begin{tabular}{|c|c|c|c|c|c|c|c|}
\hline \multirow[b]{3}{*}{ Parameters } & \multirow[b]{3}{*}{ Hour } & \multicolumn{6}{|l|}{ Groups } \\
\hline & & \multicolumn{3}{|l|}{ Control } & \multicolumn{3}{|l|}{$500 \mathrm{ppm}$} \\
\hline & & $\mathrm{C} 1$ & $\mathrm{C} 2$ & $\mathrm{C} 3$ & $\mathrm{P} 1$ & P2 & P3 \\
\hline \multirow[t]{3}{*}{$\begin{array}{l}\text { WBC } \\
\left(10^{3} \mu \mathrm{L}^{-1}\right)\end{array}$} & 0 & $8.00 \pm 0.50^{\mathrm{a} 1}$ & $8.43 \pm 0.31^{\mathrm{b} 1}$ & $8.53 \pm 0.43^{\mathrm{c} 1}$ & $8.13 \pm 0.32^{\mathrm{a} 1}$ & $8.13 \pm 0.27^{\mathrm{a} 1}$ & $8.03 \pm 0.34^{\mathrm{a} 1}$ \\
\hline & 24 & $8.50 \pm 0.18^{\mathrm{a} 2}$ & $10.43 \pm 0.42^{\mathrm{b} 2}$ & $11.70 \pm 0.41^{\mathrm{c} 2}$ & $8.43 \pm 0.22^{\mathrm{a} 2}$ & $8.56 \pm 0.22^{\mathrm{a} 2}$ & $8.36 \pm 0.22^{\mathrm{a} 2}$ \\
\hline & 48 & $8.33 \pm 0.19^{\mathrm{a} 2}$ & $9.13 \pm 0.44^{\mathrm{b} 2}$ & $12.36 \pm 0.19^{\mathrm{c} 2}$ & $8.43 \pm 0.13^{\mathrm{a} 2}$ & $8.90 \pm 0.25^{\mathrm{a} 2}$ & $8.86 \pm 0.22^{\mathrm{a} 2}$ \\
\hline \multirow[t]{3}{*}{$\begin{array}{l}\mathrm{RBC} \\
\left(10^{6} \mu \mathrm{L}^{-1}\right)\end{array}$} & 0 & $1.43 \pm 0.13^{\mathrm{a} 1}$ & $1.83 \pm 0.50^{\mathrm{a}}$ & $1.66 \pm 0.27^{\mathrm{a}}$ & $1.70 \pm 0.18^{\mathrm{a}}$ & $1.76 \pm 0.22^{\mathrm{a}}$ & $1.70 \pm 0.25^{\mathrm{a}}$ \\
\hline & 24 & $1.76 \pm 0.26^{\mathrm{a}}$ & $1.80 \pm 0.18^{\mathrm{a}}$ & $1.66 \pm 0.19^{\mathrm{a}}$ & $1.76 \pm 0.22^{\mathrm{a}}$ & $1.70 \pm 0.18^{\mathrm{a}}$ & $1.73 \pm 0.13^{\mathrm{a}}$ \\
\hline & 48 & $1.66 \pm 0.13^{\mathrm{a}}$ & $1.73 \pm 0.13^{\mathrm{a}}$ & $1.73 \pm 0.22^{\mathrm{a}}$ & $1.80 \pm 0.18^{\mathrm{a}}$ & $1.63 \pm 0.22^{\mathrm{a}}$ & $1.66 \pm 0.13^{\mathrm{a}}$ \\
\hline \multirow[t]{3}{*}{$\begin{array}{l}\mathrm{Hb} \\
\left(\mathrm{g} \mathrm{dL}^{-1}\right)\end{array}$} & 0 & $6.00 \pm 1.41 \mathrm{a}$ & $6.66 \pm 1.49 \mathrm{a}$ & $6.00 \pm 1.41^{\mathrm{a}}$ & $6.33 \pm 1.45^{\mathrm{a}}$ & $5.33 \pm 1.33^{\mathrm{a}}$ & $6.66 \pm 1.49^{\mathrm{a}}$ \\
\hline & 24 & $6.33 \pm 1.45^{\mathrm{a}}$ & $5.33 \pm 1.33^{\mathrm{a}}$ & $6.33 \pm 1.45^{\mathrm{a}}$ & $6.66 \pm 1.49^{\mathrm{a}}$ & $5.66 \pm 1.37^{\mathrm{a}}$ & $6.33 \pm 1.45^{\mathrm{a}}$ \\
\hline & 48 & $6.66 \pm 1.49^{\mathrm{a}}$ & $6.66 \pm 1.49^{\mathrm{a}}$ & $6.00 \pm 1.41^{\mathrm{a}}$ & $7.00 \pm 1.52^{\mathrm{a}}$ & $5.66 \pm 1.37^{\mathrm{a}}$ & $6.33 \pm 1.45^{\mathrm{a}}$ \\
\hline \multirow[t]{3}{*}{ Hct $(\%)$} & 0 & $16.33 \pm 0.91^{\mathrm{a}}$ & $20.66 \pm 1.53^{\mathrm{a}}$ & $19.00 \pm 1.57^{\mathrm{a}}$ & $15.66 \pm 0.43^{\mathrm{a}}$ & $17.66 \pm 0.71^{\mathrm{a}}$ & $16.66 \pm 0.71^{\mathrm{a}}$ \\
\hline & 24 & $18.33 \pm 0.83^{\mathrm{a}}$ & $17.00 \pm 0.57^{\mathrm{a}}$ & $17.00 \pm 0.75^{\mathrm{a}}$ & $18.33 \pm 0.43^{\mathrm{a}}$ & $17.00 \pm 0.57^{\mathrm{a}}$ & $17.33 \pm 0.71^{\mathrm{a}}$ \\
\hline & 48 & $16.66 \pm 0.62^{\mathrm{a}}$ & $18.00 \pm 0.57^{\mathrm{a}}$ & $17.33 \pm 0.71^{\mathrm{a}}$ & $16.66 \pm 0.43^{\mathrm{a}}$ & $18.33 \pm 0.43^{\mathrm{a}}$ & $16.66 \pm 0.43^{\mathrm{a}}$ \\
\hline \multirow[t]{3}{*}{$\begin{array}{l}\text { PLT } \\
\left(10^{3} \mu \mathrm{L}^{-1}\right)\end{array}$} & 0 & $36.66 \pm 1.20^{\mathrm{a} 1}$ & $34.00 \pm 0.93^{\mathrm{a} 1}$ & $34.66 \pm 1.03^{\mathrm{a} 1}$ & $33.00 \pm 0.57^{\mathrm{a} 1}$ & $40.00 \pm 1.20^{\mathrm{b} 1}$ & $34.33 \pm 1.58^{\mathrm{b} 1}$ \\
\hline & 24 & $41.66 \pm 1.78^{\mathrm{a} 2}$ & $32.00 \pm 1.47^{\mathrm{a} 2}$ & $40.00 \pm 1.07^{\mathrm{a} 2}$ & $33.33 \pm 0.43^{\mathrm{a} 2}$ & $46.00 \pm 1.81^{\mathrm{b} 2}$ & $49.33 \pm 1.28^{\mathrm{b} 2}$ \\
\hline & 48 & $31.66 \pm 0.71^{\mathrm{a} 1}$ & $32.00 \pm 0.75^{\mathrm{a} 1}$ & $33.33 \pm 0.71^{\mathrm{a} 2}$ & $31.66 \pm 0.98^{\mathrm{a} 1}$ & $33.00 \pm 0.57^{\mathrm{b} 1}$ & $34.00 \pm 0.57^{\mathrm{b} 1}$ \\
\hline
\end{tabular}

Different letter indexes $(\mathrm{a}, \mathrm{b}, \mathrm{c})$ indicate significantly different means for different treatments at $\mathrm{P}<0.05$. Different numerical indexes $(1,2)$ indicate significantly different means at different times at $\mathrm{P}<0.05$. Note: WBC - White blood cell; RBC - Red blood cell; Hb - Hemoglobin; Htc - Hematocrit; PLT - Platelet. C1 - control with no injection; C2 - control with $20 \mu \mathrm{L}$ normal saline injection; C3 - control with $20 \mu \mathrm{L}$ A. hydrophila injection; P1 - 500 ppm T. catappa leaf extract (TCE) immersion with no challenge; P2 - 500 ppm TCE immersion with $20 \mu \mathrm{L}$ normal saline injection; P3 - 500 ppm TCE immersion with $20 \mu \mathrm{L} A$. hydrophila injection.

group. Similar results reported on previous work indicate that Nile tilapia immersed in extracts of Asparagus racemosus (Mukherjee et al. 2015) and Neobenedenia sp. with Allium sativum (Militz et al. 2014) had significantly better survival than did controls without immersion. The high survival percentage of fish in different treatments could indicate that the phytochemical content in the plant extracts contributed to improved fish health.

Phytochemical extracts from various parts of plants were shown to enhance survival rates in common carp (C. carpio), marine ornamental fish
(Balachandran and Tissera 2013), and tilapia ( $O$. niloticus) (Akinwande et al. 2011). Plants, especially T. catappa, are rich in a wide variety of secondary metabolite phytochemicals such as tannins and saponin (Citarasu 2010, Nugroho et al. 2016). Cultured post-larval black tiger shrimp ( $P$. monodon) treated with the tannins in TCE had significantly higher survival rates (Ikhwanuddin et al. 2014). According to Van-Sumere et al. (1975) and Ashraf and Bengston (2007), tannin can absorb harmful chemicals and provide a soothing, suitable environment that is fairly benign for fish. Besides tannin, the 
biological effects of saponin, including survival and immune system stimulation in fish, have also been widely studied and reviewed. Saponins are found in plants containing either a steroid or triterpenoid aglycone to which one or more sugar chains are attached (Oda et al. 2003). Furthermore, the application of 1 and $2 \mathrm{mg} \mathrm{L}^{-1}$ saponin in white shrimp, Litopenaeus vannamei, increased their survival rate (Su and Chen 2008). On the other hand, it was observed that pure saponin at high levels caused stress symptoms and mortality following exposure to 200 $\mathrm{mg} \mathrm{L}^{-1}$ of pure saponin (Nagesh et al. 1999).

\section{Blood Profile}

Determining how phytochemicals are related to hematological indices is common in the culture of aquatic animals, including fish. Hematological parameters are used as indicators of the response of fish health status, especially in the presence of disease and under stressful conditions (Osman et al. 2010, Karimi et al. 2013, Suely et al. 2016). Hematological indices such as WBC, RBC, $\mathrm{Hb}$, the number and percentage of lymphocytes, monocytes, and granulocytes play important roles in assessing the physiological condition of fish.

Based on the current results, it was found that the WBC count of control subgroups of fish challenged with $A$. hydrophila had significantly increased $24 \mathrm{~h}$ post injection, whereas the number of WBC of all the subgroups of immersed-fish were not significantly different. Meanwhile, the RBC, $\mathrm{Hb}$, and Hct of all the subgroups of fish during the challenge test were not affected. These results are in agreement with previous findings that indicate there was an increasing number of WBC in Nile tilapia after infection (Martins et al. 2009). Pourmoghim et al. (2015) also found similar results in that dietary Origanum vulgare extract incorporated into test diets had no significant effect on RBC, WBC, Hct, hemoglobin, or Hb.

The underlying mechanism(s) whereby the WBC of TCE-immersed fish did was not altered is not properly understood. However, Rattanachaikunsopon and Phumkhachorn (2010) and Reverter et al. (2014) reported that flavonoids from plant metabolites may contribute to antibacterial activity. Flavonoids contained in TCE were able to inhibit bacterial growth. Thus, it is clear that the WBC counts of the subgroup of fish immersed in TCE did not change. Additionally, flavonoid has a positive effect in reducing RBC hemolysis which can be caused by bacterial infection, by protecting the biological membranes of the RBC (Kitagawa et al. 1992, Asgary et al. 2005). Some investigators also report that the antioxidants present in plant extracts might trigger erythropoiesis. This seems to be in agreement with the present study as TCE has flavonoid that, as an antioxidant, might maintain the heme iron in its ferrous state (Akah et al. 2007, Uboh et al. 2010, Shatoor 2011).

Besides total WBC, differential WBC such as lymphocytes, monocytes, and granulocytes produce antibodies to acknowledge and respond to the antigen and to act as mediators of cellular and humoral immune responses (Abbas et al. 2010, Soltanian and Fereidouni 2016). The current results found that fish immersed in $500 \mathrm{ppm}$ TCE had the lowest percentage of lymphocytes but the highest percentage of monocytes and granulocytes. The number of lymphocytes of all the subgroups of fish was stable during the challenge test, whereas the number of monocytes and granulocytes of all the subgroups of fish were significantly increased $24 \mathrm{~h}$ post challenge. The highest number of monocytes and granulocytes were noted in the TCE-immersed fish challenged with A. hydrophila $48 \mathrm{~h}$ post injection. The significant increase in monocytes and granulocytes in this study is in agreement with Gabriel et al. (2015) who reports that the percentage of monocytes and granulocytes in tilapia (GIFT) infected with Streptococcus iniae increased after the challenge test. Additionally, Aly et al. (2015) report that Nile tilapia vaccinated with $A$. hydrophila had no significant different lymphocyte values compared to unvaccinated Nile tilapia.

The increase in monocyte and granulocytes in TCE-immersed fish can be attributed to the improvement of non-specific immune responses. However, the number of lymphocytes that was stable during the challenge test may indicate that there was no 
enhancement in specific immune induction. Monocytes play a pivotal role in the immune defense system of fish. They can transform into macrophages and exhibit phagocytosis activity against pathogens at first recognition and subsequent infections. Granulocytes, such as neutrophils, are the primary cells responsible for first infections and the phagocytosis of bacterial pathogens during challenge tests (Sivagurunathan et al. 2011).

\section{Conclusions}

In summary, this study indicates that 500 ppm TCE immersion can potentially be used to combat $A$. hydrophila as it increases the survival and hematological profile, such as the number and percentage of monocytes and granulocytes, of Betta sp. The study has also shown that the application of TCE might also be of practical use in disease management strategies in fish, especially the ornamental fish Betta sp. Further research needs to be conducted to examine the lysozyme activity, respiratory burst, and the antioxidant profiles of fish immersed in 500 ppm TCE.

Acknowledgement. The authors are grateful to the Research, Technology, and General Higher Education Ministry, Government of Indonesia for financial support No. 079/UN17.41/LT/2016 SP DIPA-042.06.1.401516/

2016. The authors also extend their gratitude to the following: Mulawarman University, especially the Department of Biology, Faculty of Mathematics and Natural Sciences for their support.

Author contributions. R.A.N. and H.M. conceived and designed the experiments, and performed the experiments, R.A.N., H.M., F.M.N., and W.P. collected the data, R.A.N., H.M., and W.P. wrote the paper, R.A.N., and H.M. read and approved the final manuscript.

\section{References}

Abbas A.K., Lichtman A.H., Pillai S. 2010 - Cellular and molecular immunology - Saunders Company, Philadelphia: 544 p.
Abdel-Tawwab M., Ahmad M.H., Seden M.E.A., Sakr S.F.M. 2010 - Use of green tea, Camellia sinensis L., in practical diet for growth and protection of nile tilapia, Oreochromis niloticus (L.), against Aeromonas hydrophila infection - J. World Aquacult. Soc. 41: 203-213.

Abdi K., Azadikhah D., Fard A.N. 2014 - Occurrence reported the Aeromonas sobria infection in Goldfish (Carassius auratus) - Iranian journal congress, At Teheran.

Adel M., Pourgholam R., Zorriehzahra J., Ghiasi M. 2016 Hemato-Immunological and biochemical parameters, skin antibacterial activity, and survival in rainbow trout (Oncorhynchus mykiss) following the diet supplemented with Mentha piperita against Yersinia ruckeri - Fish Shellfish Immunol. 55: 267-273.

Akah PA., Okpi O., Okoli C.O. 2007 - Evaluation of the anti-inflammatory, analgesic and antimicrobial activities of bark of Afzelia africana - Nig. J. Nat. Prod. Med. 11: 48-52.

Akinwande A., Dada A.A., Moody F.O. 2011 - Effect of dietary administration of the phytochemical "genistein"(3,5,7,3,4 pentahydroxyflavone) on masculine tilapia, Oreochromis niloticus - Elixir Aqua. 33: 2231-2233.

Alfian. 2010 - Indonesian ornamental fish: Redifining the global status - In: Export News Indonesia (Eds) H.I. Kresnarini, H.I. Widayanti, Z. Bachtar, Jakarta, Indonesia: $10 \mathrm{p}$.

Alvarez F., Razquin B., Villena A., Lopez Fierro P., Zapata A. 1988 - Alterations in the peripheral lymphoid organs and differential leukocyte counts in Saprolegnia-infected brown trout, Salmo trutta fario - Vet. Immunol. Immunop. 18: 181-193.

Aly S.M., Albutti A.S., Rahmani A.H., Atti N.M. A. 2015 - The response of New-season Nile tilapia to Aeromonas hydrophila vaccine - Int. J. Clin. Exp. Med. 8: 4508-4514.

Anusha P., Thangaviji V., Velmurugan S., Michaelbabu M., Citarasu T. 2014 - Protection of ornamental gold fish Carassius auratus against Aeromonas hydrophila by treating Ixora coccinea active principles - Fish Shellfish Immunol. 36: 485-493.

Asgary S., Naderi G.H., Askari N.M.S. 2005 - Protective effect of flavonoids against red blood cell hemolysis by free radicals - Exp. Clin. Cardiol. 10: 88-90.

Ashraf M., Bengtson D.A. 2007 - Effect of tannic acid on feed intake, survival and growth of striped bass (Morone saxatilis) larvae - Int. J. Agric. Biol. 9: 751-754.

Baba E., Acar Ü., Öntaş C., Kesbiç O.S., Yilmaz S. 2016 - The use of Avena sativa extract against Aeromonas hydrophila and its effect on growth performance, hematological and immunological parameters in common carp (Cyprinus carpio) - Ital. J. Anim. Sci. 15: 1-9. 
Balachandran N., Tissera K. 2013 - A study on the effect of using mangrove leaf extracts as a feed additive in the progress of bacterial infections in marine ornamental fish - J. Coast. Life Med. 1: 217-224.

Bilen S., Ünal S., Güvensoy H. 2016 - Effects of oyster mushroom (Pleurotus ostreatus) and nettle (Urtica dioica) methanolic extracts on immune responses and resistance to Aeromonas hydrophila in rainbow trout (Oncorhynchus mykiss) - Aquaculture 454: 90-94.

Blaxhall B.R., Rao K.S. 1973 - Routine haematological methods for use with fish blood - J. Fish Biol. 5: 771-781.

Carriero M.M., Maia M.A.A., Sousa R.L.M., Henrique-Silva F. 2016 - Characterization of a new strain of Aeromonas dhakensis isolated from diseased pacu fish (Piaractus mesopotamicus) in Brazil - J. Fish Dis. 39: 1285-1295.

Chakraborty S.B., Hancz C. 2011 - Application of phytochemicals as immunostimulant, antipathogenic and antistress agents in finfish culture - Rev. Aquacult. 3: 103-119.

Chakraborty S.B., Horn P., Hancz C. 2014 - Application of phytochemicals as growth-promoters and endocrine modulators in fish culture - Rev. Aquacult. 6: 1-19.

Chandel A.K., Narasu M.L., Chandrasekhar G., Manikyam A., Venkateswar R.L. 2009 - Use of Saccharum spontaneum (wild sugarcane) as biomaterial for cell immobilization and modulated ethanol production by thermotolerant Saccharomyces cerevisiae VS3 - Bioresource Technol. 100: 2404-2410.

Chitmanat C., Tongdonmuan K., Khanom P., Pachontis P., Nunsong W. 2003 - Antiparasitic, antibacterial, and antifungal activities derived from a Terminalia catappa solution against some tilapia (Oreochromis niloticus) pathogens - In: III WOCMAP Congress on medicinal and aromatic plants-volume 4: Targeted screening of medicinal and aromatic plants, Economics 678: 179-182.

Citarasu T. 2010 - Herbal biomedicines: a new opportunity for aquaculture industry - Aquacult. Int. 18: 403-414.

Das R., Raman R.P., Saha H., Singh R. 2015 - Effect of Ocimum sanctum Linn. (Tulsi) extract on the immunity and survival of Labeo rohita (Hamilton) infected with Aeromonas hydrophila - Aquacult. Res. 46: 1111-1121.

Devi K.N., Dhayanithi N.B., Kumar T.T.A., Balasundaram C., Harikrishnan R. 2016 - In vitro and in vivo efficacy of partially purified herbal extracts against bacterial fish pathogens - Aquaculture 458: 121-133.

Do Huu H., Sang H.M., Thanh Thuy N.T. 2016 - Dietary $\beta$-glucan improved growth performance, Vibrio counts, haematological parameters and stress resistance of pompano fish, Trachinotus ovatus Linnaeus, 1758 - Fish Shellfish Immunol. 54: 402-410.

Ekman A., Wallberg O., Joelsson E., Börjesson P. 2013 - Possibilities for sustainable biorefineries based on agricultural residues - A case study of potential straw-based ethanol production in Sweden - Appl. Energ. 102: 299-308.

Gabriel N.N., Qiang J., He J., Ma X.Y., Kpundeh M.D., Xu P. 2015 - Dietary Aloe vera supplementation on growth performance, some haemato-biochemical parameters and disease resistance against Streptococcus iniae in tilapia (GIFT) - Fish Shellfish Immunol. 44: 504-514.

Goh C.S., Tan K.T., Lee K.T., Bhatia S. 2010 - Bio-ethanol from lignocellulose: Status, perspectives and challenges in Malaysia - Bioresource Technol. 101: 4834-4841.

Guz L., Kozinska A. 2004 - Antibiotic susceptibility of Aeromonas hydrophila and A. sobria isolated from farmed carp (Cyprinus carpio L.) - Bull. Vet. Inst. Puławy, 48: 391-395.

Harikrishnan R., Balasundaram C., Heo M.S. 2015 - Effect of chemotherapy, vaccines and immunostimulants on innate immunity of goldfish infected with Aeromonas hydrophila - Dis. Aquat. Org. 88: 45-54.

He X., Deng M., Wang Q., Yang Y., Yang Y., Nie X. 2016 Residues and health risk assessment of quinolones and sulfonamides in cultured fish from Pearl River Delta, China - Aquaculture 458: 38-46.

Hyttel P., Sinowatz F., Vejlsted M.K. 2010 - Essentials of domestic animal embryology - Elsevier Saunders, London, UK: 472 p.

Ikhwanuddin M., Moh J.H., Hidayah M., Noor-Hidayati A.B., Aina-Lyana N.M., Nor Juneta A.S. 2014 - Effect of Indian almond, Terminalia catappa leaves water extract on the survival rate and growth performance of black tiger shrimp, Penaeus monodon post larvae - AACL Bioflux, 7: 85-93.

Immanuel G., Uma R.P., Iyapparaj P., Citarasu T., Peter S.M., Babu M.M., Palavesam A. 2009 - Dietary medicinal plant extracts improve growth, immune activity and survival of tilapia Oreochromis mossambicus - J. Fish Biol. 74: 1462-1475.

Inama L., Diré S., Carturan G., Cavazza A. 1993 - Entrapment of viable microorganisms by $\mathrm{SiO} 2$ sol-gel layers on glass surfaces: Trapping, catalytic performance and immobilization durability of Saccharomyces cerevisiae - J. Biotechnol. 30: 197-210.

Julius O.O., Mariatu K. 2015 - Effect of Terminalia catappa on growth and heamatology of Clarias gariepinus juveniles - J. Aquacult. Feed Sci. Tech. 7: 1-5

Kakaei S., Shahbazi Y. 2016 - Effect of chitosan-gelatin film incorporated with ethanolic red grape seed extract and Ziziphora clinopodioides essential oil on survival of Listeria monocytogenes and chemical, microbial and sensory properties of minced trout fillet - LWT - Food Sci. Technol. 72: 432-438.

Karimi S.H., Kochinian P., Salati A.P. 2013 - The effect of sexuality on some haematological parameters of the yellowfin seabream, Acanthopagrus latus in Persian Gulf - Iran J. Vet. Res. 14: 65-68. 
Kirubakaran C.J.W., Subramani P.A., Michael R.D. 2016 Methanol extract of Nyctanthes arbortristis seeds enhances non-specific immune responses and protects Oreochromis mossambicus (Peters) against Aeromonas hydrophila infection - Res. Vet. Sci. 105: 243-248.

Kitagawa S., Fujisawa H., Sakura H. 1992 - Scavenging effects of dihydric and polyhydric phenols on superoxide anion radicals, studied by electron spin resonance spectrometry - Chem. Pharm. Bull. 40: 304-307.

Lee S.W., Sim K.Y., Wendy W., Zulhisyam A.K. 2016 Peperomia pellucida leaf extract as immunostimulator in controlling motile aeromonad septicemia due to Aeromonas hydrophila in red hybrid tilapia, Oreochromis spp. farming - Vet. World. 9: 231-234.

Madhuri S., Mandloi A.K., Govind P., Sahni Y.P. 2013 Antimicrobial activity of some medicinal plants againts fish pathogen - IRJP 3: 28-30.

Majtán J., Černy J., Ofúkaná A., Takáč P., Kozánek M. 2012 Mortality of therapeutic fish Garra rufa caused by Aeromonas sobria - APJTB 2: 85-87.

Maliwat G.C., Velasquez S., Robil J.L., Chan M., Traifalgar R.F., Tayamen M., Ragaza J.A. 2016 - Growth and immune response of giant freshwater prawn Macrobrachium rosenbergii (De Man) postlarvae fed diets containing Chlorella vulgaris (Beijerinck) Aquacult. Res. 48: 1666-1676.

Martins M.L., Vieira F.N., Jerônimo G.T., Mourino J.L., Dotta G., Speck G.M., Bezerra A.J., Pedrotti F.S., Buglione-Neto C.C., Pereira G. Jr. 2009 - Leukocyte response and phagocytic activity in Nile tilapia experimentally infected with Enterococcus sp. - Fish Physiol. Biochem. 35: 219-222.

Meena K., Raja T.K. 2006 - Immobilization of Saccharomyces cerevisiae cells by gel entrapment using various metal alginates - World J. Microbiol. Biotechnol. 22: 651-653.

Middleton E., Jr. 1998 - Effect of plant flavonoids on immune and inflammatory cell function - Adv. Exp. Med. Biol. 439: 175-182.

Middleton E. Jr., Kandaswami C. 1992 - Effects of flavonoids on immune and inflammatory cell functions - Biochem. Pharmacol. 43: 1167-1179.

Militz T.A., Southgate P.C., Carton A.G., Hutson K.S. 2014 Efficacy of garlic (Allium sativum) extract applied as a therapeutic immersion treatment for Neobenedenia sp. management in aquaculture - J. Fish Dis. 37: 451-461.

Modrá H., Svobodová Z., Kolářová J. 1998 - Comparison of differential leukocyte counts in fish of economic and indicator importance - Acta Vet. Brno. 67: 215-226.

Mukherjee D., Ghosal I., Chakraborty S.B. 2015 - Application Of Asparagus racemosus Roots for Production Of Monosex Nile Tilapia, Oreochromis niloticus - IJAR 3: 828-833.

Musthafa M.S., Ali A.R.J., Mohamed M.J., Jaleel M.M.A., Kumar M.S.A., Rani K.U. 2016 - Protective efficacy of azomite enriched diet in Oreochromis mossambicus against Aeromonas hydrophila - Aquaculture 451: 310-315.

Nagesh T.S., Jayabalan N., Mohan C.V., Annappaswamy T.S., Anil T.M. 1999 - Survival and histological alterations in juvenile tiger shrimps exposed to saponin - Aquacult. Int. 7: 159-167.

Ni P-J., Jiang W-D., Wu P., Liu Y., Kuang S-Y., Tang L., Tang W-N., Zhang Y-A., Zhou X.Q., Feng L. 2016 - Dietary low or excess levels of lipids reduced growth performance, and impaired immune function and structure of head kidney, spleen and skin in young grass carp (Ctenopharyngodon idella) under the infection of Aeromonas hydrophila - Fish Shellfish Immunol. 55: 28-47.

Nugroho R.A., Manurung H., Saraswati D., Ladyescha D., Nur F.M. 2016 - The Effects of Terminalia catappa L. Leaves Extract on the Water Quality Properties, Survival and Blood Profile of Ornamental fish (Betta sp.) Cultured - Biosaintifika: J. Biol. Educ. 8: 241-248.

Oda K., Matsuda H., Murakami T., Katayama S., Ohgitani T., Yoshikawa M. 2003 - Relationship between adjuvant activity and amphipathic structure of soyasaponins Vaccine 21: 2145-2151.

Osman A.G.M., Koutb M., Sayed A. E-D.H. 2010 - Use of hematological parameters to assess the efficiency of quince (Cydonia oblonga Miller) leaf extract in alleviation of the effect of ultraviolet - A radiation on African catfish Clarias gariepinus (Burchell, 1822) - J. Photoch. Photobio. B. 99: 1-8.

Öztop H.N., Öztop A.Y., Işikver Y., Saraydin D. 2002 - Immobilization of Saccharomyces cerevisiae on to radiation crosslinked HEMA/AAm hydrogels for production of ethyl alcohol - Process Biochem. 37: 651-657.

Pandey G. 2013 - Some medicinal plants to treat fish ectoparasitic infections - IJPSR 2:532-538.

Pourmoghim H., Haghighi M., Rohani M.S. 2015 - Effect of dietary inclusion of Origanum vulgare extract on non-specific immune responses and hematological parameters of rainbow trout (Oncorhynchus mykiss) Bull. Env. Pharmacol. Life Sci. 4: 33-39.

Rakholiya K., Chanda S. 2012 - In vitro interaction of certain antimicrobial agents in combination with plant extracts against some pathogenic bacterial strains - Asian Pac. J. Trop. Biomed. 2: 876-880.

Rattanachaikunsopon P., Phumkhachorn P. 2010 - Contents and antibacterial activity of flavonoids extracted from leaves of Psidium guajava - J. Med. Plants Res. 4: 393-396.

Reverter M., Bontemps N., Lecchini D., Banaigs B., Sasal P. 2014 - Use of plant extracts in fish aquaculture as an alternative to chemotherapy: Current status and future perspectives - Aquaculture 433: 50-61. 
Sahoo P.K., Swaminathan T.R., Abraham T.J., Kumar R., Pattanayak S., Mohapatra A., Rath S.S., Patra A., Adikesavalu H., Sood N., Pradhan P.K., Das B.K., Jayasankar P., Jena J.K. 2016 - Detection of goldfish haematopoietic necrosis herpes virus (Cyprinid herpesvirus-2) with multi-drug resistant Aeromonas hydrophila infection in goldfish: First evidence of any viral disease outbreak in ornamental freshwater aquaculture farms in India - Acta Trop. 161: 8-17.

Samanidou V.F., Evaggelopoulou E.N. 2007 - Analytical strategies to determine antibiotic residues in fish - J. Sep. Sci. 30: 2549-2569.

Saroja M., Santhi R., Annapoorani S. 2012 - Evaluation of antitumor and antioxidant activity of flavonoid fraction of Terminalia catappa against ehrlich ascites carcinoma in mice - Int. J. Drug Dev. Res. 4: 180-187.

Shatoor A.S. 2011 - Acute and sub-acute toxicity of Crataegus aronia syn. azarolus (L.) whole plant aqueous extract in wistar rats - Am. J. Pharmacol. Toxicol. 6: 37-45.

Sinclair H.A., Heney C., Sidjabat H.E., George N.M., Bergh H., Anuj S.N., Nimmo G.R., Paterson D.L. 2016 - Genotypic and phenotypic identification of Aeromonas species and CphA-mediated carbapenem resistance in Queensland, Australia - Diagn. Microbiol. Infect. Dis. 85: 98-101.

Sivagurunathan A., Meera K.A., Innocent B.X. 2011 - Investigation of immunostimulant potential of Zingiber officinale and Curcuma longa in Cirrhinus mrigala exposed to Pseudomonas aeruginosa - haematological assessment - Int. J. Res. Ayurveda Pharm. 2: 899-904.

Sivasankar P., Anix Vivek Santhiya A., Kanaga V. 2015 - A review on plants and herbal extracts against viral diseases in aquaculture - J. Med. Plants. 3: 75-79.

Soltanian S., Fereidouni M.S. 2016 - Effect of henna (Lawsonia inermis) extract on the immunity and survival of common carp, Cyprinus carpio infected with Aeromonas hydrophila - Int. Aquat. Res.: 1-15.

Su B.K., Chen J.C. 2008 - Effect of saponin immersion on enhancement of the immune response of white shrimp
Litopenaeus vannamei and its resistance against Vibrio alginolyticus - Fish Shellfish Immunol. 24: 74-81.

Suely A., Zabed H., Ahmed A.B.A., Mohamad J., Nasiruddin M., Sahu J.N., Ganesan P. 2016 - Toxicological and hematological effect of Terminalia arjuna bark extract on a freshwater catfish, Heteropneustes fossilis - Fish Physiol. Biochem. 42: 431-444.

Syahidah A., Saad C.R., Daud H.M., Abdelhadi Y.M. 2015 Status and potential of herbal applications in aquaculture: A review - Iran. J. Fish. Sci. 14: 27-44.

Tamamdusturi R., Yuhana M. 2016 - Administration of microencapsulated probiotic Bacillus sp. NP5 and prebiotic mannan oligosaccharide for prevention of Aeromonas hydrophila infection on Pangasianodon hypophthalmus - J. Fish. Aquat. Sci. 11: 67.

Uboh F.E., Okon I.E., Ekong M.B. 2010 - Effect of aqueous extract of Psidium guajava leaves on liver enzymes, histological integrity and hematological indices in rats Gastroenterol. Res. 3: 32-38.

Uchida K., Konishi Y., Harada K., Okihashi M., Yamaguchi T., Do M.H.N., Thi Bui L., Duc Nguyen T., Do Nguyen P., Thi Khong D., Thi Tran H., Nam Nguyen T., Viet Le H., Van Chau V., Thi Van Dao K., Thi Ngoc Nguyen H., Kajimura K., Kumeda Y., Tran Pham K., Ngoc Pham K., Trong Bui C., Quang Vien M., Hoang Le N., Van Dang C., Hirata K., Yamamoto Y. 2016 - Monitoring of antibiotic residues in aquatic products in urban and rural areas of Vietnam - J. Agric. Food Chem. 64: 6133-6138.

Van-Sumere C.F., Albrecht J., Dedonder A., Depooter H., Pe I. 1975 - Plant proteins and phenolics - In: Annual Proceedings of phytochemistry Society, 211-264.

Vučurović V.M., Razmovski R.N. 2012 - Sugar beet pulp as support for Saccharomyces cerivisiae immobilization in bioethanol production - Ind. Crops Prod. 39: 128-134.

Yang W., Li N., Li M., Zhang D., An G. 2016 - Complete Genome Sequence of Fish Pathogen Aeromonas hydrophila JBN2301 - Genome Announc. 4: e01615-15.

Zhou Z.D., Li G.Y., Li Y J. 2010 - Immobilization of Saccharomyces cerevisiae alcohol dehydrogenase on hybrid alginate-chitosan beads - Int. J. Biol. Macromol. 47: 21-26. 